\title{
Hydroxychloroquine Efficacy for the Treatment of Patients with COVID-19: A Systematic Review and Meta-Analysis
}

Nayara Izabel Viana

University of Sao Paulo

Ruan Pimenta

University of Sao Paulo

Guilherme Lopes Gonçalves

University of Sao Paulo

Thaynara Faria Gomes

Faculdade Atenas

Vanessa Ribeiro Guimarães

University of Sao Paulo

Victor Srougi

University of Sao Paulo, Moriah Hospital

Miguel Srougi

University of Sao Paulo, Moriah Hospital

Katia R. Leite

University of Sao Paulo

Sabrina T. Reis ( $\nabla$ sasareis@gmail.com )

University of Sao Paulo

\section{Systematic Review}

Keywords: SARS-CoV-2, COVID-19, Hydroxychloroquine, Meta-analysis, Coronavirus

Posted Date: June 2nd, 2020

DOl: https://doi.org/10.21203/rs.3.rs-33160/v1

License: (1) (i) This work is licensed under a Creative Commons Attribution 4.0 International License.

Read Full License 


\section{Abstract}

Background and Purpose. COVID-19 (Coronavirus Disease - 2019) represents a public health emergency because of the elevated transmission rates and associated mortality. There is an urgent need to limit the spread of the virus and to develop an effective antiviral treatment for the patients harboring such disease. This meta-analysis aimed to evaluate the results of the existing randomized clinical trials assessing the use of Hydroxychloroquine (HCQ) to treat COVID-19.

Methods. A systematic review was performed on PubMed and Google Scholar according to the Preferred Reporting Items for Systematic Review and Meta-analysis (PRISMA) recommendations. Information from randomized controlled trials (RCT) was retrieved and included in a meta-analysis.

Results. Among 214 studies that were found, 3 were included for in the meta- analysis. Patients treated with HCQ had a faster clearance of virus or pneumonia improvement than those that received standard treatment $(\mathrm{OR}=7.08,95 \% \mathrm{Cl} 2.79$ to $4.12 ; \mathrm{P}=0.001)$. Only minor side effects were reported.

Conclusions. Although this meta-analysis has found favorable evidence for the use of HCQ in the treatment of COVID-19, the literature does not yet present well-designed clinical studies that demonstrate the effectiveness of this medication. We believe that clinical trials coordinated by standardized guidelines, with complete and quality information, must be carried out worldwide and are urgently needed.

\section{Introduction}

COVID-19 (Coronavirus Disease - 2019) represents a public health emergency, which started in December 2019 in Wuhan, China, and on March 12, 2020 was declared a pandemic by the World Health Organization ${ }^{1}$. Worldwide, as of that date (04/26/2020), there are 195 affected countries, more than $2,900,000$ confirmed cases and 203,000 deaths, although the actual rates may be higher, considering the absence of confirmatory tests for suspected cases in some regions ${ }^{2}$. Among those infected, $15 \%$ progress to the most severe form of the disease. According to a recent study from China, the mortality rate is $2.3 \%$, however, in patients aged 70 to 79 years the rate is $8 \%$ and in patients aged $\geq 80$ years it reaches $14.8 \%{ }^{3}$. It has been shown that patients with hypertension and/or diabetes have a higher risk of contracting COVID-19 ${ }^{4}$. Most patients (80\%) have a moderate presentation of the disease, without the presence of Severe Acute Respiratory Syndrome (SARS) ${ }^{5}$. However, in the absence of effective treatment, these patients can progress to the severe form of the disease, developing SARS (due to activation of the cytokine cascade in a short period) and multiple organ failure ${ }^{6,7}$. These conditions could be responsible for the high mortality rates.

Limiting the transmission of the virus is a priority, as the development of effective antiviral treatment for patients with mild symptoms, which can progress to severe ones. Clinical trials are ongoing, but there is still no pharmacological treatment proven by randomized studies ${ }^{4}$. 
Chloroquine, an immunomodulant traditionally used to treat malaria, has been explored in vitro and demonstrated effectiveness in reducing viral replication of SARS- associated coronavirus (CoV) and MERS-CoV ${ }^{8,9}$. Although this drug has been used globally for over 70 years, it is a promising candidate for the treatment of COVID-19 because of its low cost, clinical safety profile and already established dosages and drug interactions ${ }^{9,10}$. Nevertheless, the use of chloroquine in the treatment of SARS-CoV-2 pneumonia (a new virus that causes COVID-19) needs to be proven effective.

Wang et al. ${ }^{11}$ reported the inhibitory effect of chloroquine on the growth of SARS- CoV-2 in vitro. In an initial clinical trial with Chinese patients with COVID-19, it was observed that chloroquine had a significant effect on clinical improvement and viral clearance ${ }^{12,13}$.

Hydroxychloroquine (HCQ) is a chloroquine analog that has better clinical safety, allows administration

of higher daily doses and presents fewer problems with drug interactions ${ }^{14,15}$. In vitro experiments also demonstrated the efficiency of HCQ in blocking SARS-CoV activity ${ }^{16}$. Given the importance to find an effective treatment for COVID-19, we performed a systematic review and meta-analysis of the randomized clinical trials that analyzed the use of HCQ in patients with COVID-19.

\section{Methods}

According to the PICO recommendations, the question that oriented this systematic review was: Is HCQ effective in treating COVID-19 compared to standard treatment?

We performed a systematic review and meta-analysis of PubMed and Google Scholar databases on April 1,2020 to find articles providing information on the efficacy and safety of chloroquine and chloroquine analogs in patients with SARS-CoV-2 pneumonia. The search was expanded using the snowballing method, applied to the references of the retrieved papers. We also searched in the Brazilian Clinical Trials and the International Clinical Trials Registry Platform to identify ongoing trials. Five investigators (NIV, RP, GLG, TFG, VRG) independently screened the databases and the trial registries to extracted relevant information. This meta-analysis was registered in PROSPERO (CRD42020178832).

\section{Inclusion and exclusion criteria}

We included studies according to the following criteria: (1) Original series, (2) human research, (3) full text available, (4) title or abstract containing the keywords and (5) clinical trials. We excluded: Retrospective studies, in vitro trials, reviews, case reports, conference abstracts, letters to the editors, duplicates and trials with a lack of data. Three investigators (RP, GLG, and TFG) evaluated the full text of the selected articles independently to assess eligibility and extract data. Disagreements were resolved by consensus.

\section{Statistical analysis}

Comprehensive Meta-Analysis Software (CMA) was employed to do the meta- analysis and graph settings. Estimations of effect were summarized by forest plots. Data were expressed as risk ratios (RR) 
with $95 \%$ confidence intervals (Cl) for dichotomous outcomes.

\section{Results}

\section{Study selection}

The initial search identified 214 papers and 3 trials were included for analysis ${ }^{17-19}$ (Table 1 and figure 1). We found 43 clinical trials in progress analyzing the use of chloroquine and/or HCQ registered in the United States, China, Brazil and some European countries (Table 2). The databases searched were: clinicaltrials.gov, Agência Nacional de Vigilância Sanitária (ANVISA), Registro Brasileiro de Ensaios Clínicos, EU Clinical Trials Register and Chinese Clinical Trial Registry.

\section{Evidence synthesis}

Gautret et al. ${ }^{18}$ included 36 patients positive for SARS-CoV-2 by PCR in the nasopharyngeal sample. In this study the patients were divided into 3 groups: Control group $(n=16)$, HCQ group $(600 \mathrm{mg} /$ day of HCQ for 10 days) $(n=14)$ and HCQ plus Azithromycin group $(600 \mathrm{mg} /$ day for 10 days plus Azithromycin $500 \mathrm{mg}$ on day 1 followed by $250 \mathrm{mg} /$ day the next four days) $(n=6)$. The authors highlighted the synergistic role of HCQ and Azithromycin. However, in the present review, we sought to explore only the results between HCQ and control groups. The primary endpoint was virologic clearance measured by nasopharyngeal PCR on the sixth day after inclusion in the study. The proportion of patients that had a negative PCR tests significantly differed between treated and control groups at days 3, 4, 5 and 6 . When comparing the effect of HCQ treatment alone, the percentage of patients that had negative PCR test on the sixth-day post-inclusion was $57.1 \%$ compared to $12.5 \%$ in the control group. No side effects were mentioned in this study.

Chen et al. ${ }^{19}$ included 62 patients that were randomly divided into 2 groups, all of whom received the standard treatment (oxygen therapy, antivirals, antibacterial and immunoglobulin, with or without corticosteroids). The treatment group received $400 \mathrm{mg} /$ day of HCQ for 5 days. The control group received only the standard treatment. The endpoint was the improvement of the pneumonia measured with computed tomography. The authors observed that $61.3 \%(n=19)$ of the patients in the HCQ group had a significant improvement of pneumonia, while only $16.1 \%(n=5)$ in the control group had the same finding $(p=0.047)$. During the study, the authors reported that 4 patients of the control group progressed to severe disease and did not receive treatment with HCQ. Two patients reported mild adverse effects in the treatment group: One patient had a cutaneous rash and the other presented headaches. No severe side effects were observed during the study.

Jun et al. ${ }^{17}$ evaluated 30 patients with confirmed COVID-19 from a clinical public health center in Shanghai. The patients were divided into two groups: Control group $(n=15)$ that received standard treatment and HCQ group $(n=15)$ that received $400 \mathrm{mg} /$ day of HCQ for five days. After 7 days of treatment, the patients underwent a nasopharyngeal swab PCR test, which was negative in $86.7 \%$ of the treatment group and in $93.3 \%$ of the control group ( $p>0.05$ ). Four patients in the HCQ group had adverse 
effects, including diarrhea, marked weakness and elevation of serum aspartate aminotransferase (AST) concentration, while in the control, group 3 patients had anemia, elevation of serum AST and of creatinine. No significant differences were observed between groups regarding the incidence of adverse effects $(p>0.05)$.

Two of the included trials had a higher frequency of symptomatic patients in the treatment group at the beginning of the investigation. In contrast, in the study by Chen et al., the control group included more symptomatic patients than in the treatment group (Table 3 ).

The odds ratio (OR) was calculated based on the selected studies endpoints (pneumonia improvement or negative PCR for COVID-19 of the nasopharyngeal swab). Two studies demonstrated a significant benefit of the treatment with HCQ and the meta-analysis demonstrated that patients using HCQ have a 7-fold $(95 \% \mathrm{Cl}=2.79-4.12)$ greater chance of a favorable outcome (Figure 2).

\section{Discussion}

Considering that there is still no specific treatment for COVID-19, the identification of effective antiviral agents to foster healing of the disease is urgently needed. An efficient approach would be to testing existing antiviral drugs. Some of these drugs, such as ribavirin, and lopinavir-ritonavir have been used in patients with SARS or MERS, but their effectiveness remains uncertain ${ }^{20}$.

Chloroquine has long been used in the treatment of malaria and amoebiasis. However, Plasmodium falciparum has acquired resistance to it and with the emergence of new antimalarials, it is nowadays mostly used for the prophylaxis of the disease. Besides, chloroquine overdose can cause cardiac arrhythmia and death ${ }^{21}$. In China, in recent years, chloroquine production has been dramatically reduced due to its low use in clinical practice ${ }^{22}$.

Hydroxychloroquine sulfate was synthesized in 1946 by the introduction of a hydroxyl group in chloroquine. In animals, HCQ is less toxic when compared to chloroquine ${ }^{23}$. This medication is used to treat systemic autoimmune diseases, such as systemic lupus erythematosus and rheumatoid arthritis. Chloroquine and HCQ have similar chemical structures and mechanisms of action, and because of their anti-viral activity, both could be promising candidates for the treatment of SARS-CoV-2 infection. Hence, several studies have investigated this hypothesis in in vitro experiments.

Wang et al. ${ }^{11}$ evaluated the antiviral efficiency of five FDA-approved drugs, including ribavirin, penciclovir, nitazoxanide, nafamostat, chloroquine and two broad- spectrum antiviral drugs, remdesivir and favipiravir. Recently the 2019-nCoV clinical isolate (Vero E6 cells infected with SARS-CoV-2) was used in experiments. Remdesivir and chloroquine were highly effective in reducing viral replication. However, because it is an experimental medication, remdesivir is not available on large scale. Chloroquine showed satisfactory results with an effective concentration (EC) of $6.90 \mu \mathrm{M}$, which can be achieved with standard oral doses in humans due to its favorable penetration into tissues, including the lung. The authors 
demonstrated that chloroquine increases the endosomal $\mathrm{pH}$, interfering within the glycosylation of the SARS-CoV cell receptor and consequently blocking the infection by the virus. The authors also suggest its evaluation in patients affected by the coronavirus, considering the possibility that the immunomodulatory effect of the drug may increase the antiviral effect in vivo.

Yao et al. ${ }^{15}$ tested the pharmacological activity of chloroquine and HCQ in Vero E6 cells infected with SARS-Cov-2. Pharmacokinetic models for both drugs were tested separately, mimicking the pulmonary environment, aiming to investigate the most effective regimen according to the drug's safety profile. They concluded that HCQ is more potent than chloroquine to inhibit SARS-CoV-2 in vitro and recommended the oral administration of $400 \mathrm{mg}$ of HCQ twice daily and a maintenance dose of $200 \mathrm{mg}$ twice daily for 4 days.

Liu et al. ${ }^{22}$ also evaluated the antiviral effect of HCQ against SARS-CoV-2 infection compared to chloroquine in vitro. The tests were carried out on Vero E6 cells assessing viral activity. The authors found that HCQ inhibited virus penetration into the cell and suggested that clinical trials should be performed.

The in vitro studies mentioned above reported better performance of HCQ when compared to chloroquine for the treatment of SARS-CoV-2. In accordance, the randomized clinical trials conducted by Chen et al. and Gautret et al. ${ }^{17,18}$ included in this meta-analysis also found satisfactory results of this drug for the treatment for COVID-19. In contrast, Jun et al. ${ }^{17}$ found no benefit in the treatment with HCQ. Of note, none of the three studies analyzed here reported the occurrence of serious adverse effects in patients treated with HCQ.

Like chloroquine, we can affirm that the risk-benefit of using HCQ is favorable to the treatment of COVID19 since it has satisfactory clinical safety and low risk of interaction with other drugs ${ }^{9,14}$. To date, 195 countries have reported cases of the disease, and the low cost of this medication would be of great benefit to health systems, especially for low- and middle-income countries ${ }^{24}$.

A consensus of experts recently published by a multi-centric collaborative group from China recommended the use of chloroquine phosphate (500 mg, twice daily and for ten days) for patients diagnosed with mild, moderate and severe SARS-CoV-2 pneumonia, as long as they have no contraindications for the drug use. Other precautions were also recommended, including routine blood exams, electrocardiography and avoiding simultaneous administration of other medications ${ }^{25}$.

The Italian Society for Infectious and Tropical Diseases recommended the use of $500 \mathrm{mg}$ of chloroquine twice daily or $200 \mathrm{mg}$ of HCQ for 10 days. However, this treatment period can vary from 5 to 20 days, depending on the intensity of the symptoms presented. This recommendation can be applied for patients who have mild respiratory symptoms and for patients with severe respiratory failure ${ }^{26}$.

In our search, we found 43 clinical studies in progress evaluating the use of chloroquine and HCQ to treat COVID-19, registered in the United States of America, China, Brazil and some European countries (Table 2). The world scientific community is committed to the urgent search for effective treatments against 
COVID-19. Problems to be told, the many trials being performed at the same time will result in a lot of variation regarding the study design, the severity of the symptoms in the included patients, the dosages of medication used and the duration of the treatment. This fact may preclude the comparison of their results, revealing the need to create guidelines for effective trial coordination.

In China, a guideline has been published to coordinate and regulate clinical trials that evaluate treatment alternatives for COVID-19 ${ }^{27}$. The World Health Organization (WHO) also published a generic protocol for randomized clinical trials that aim to investigate the clinical efficacy and safety of pharmacological treatments for patients with COVID-19 28 .

This meta-analysis included the 3 clinical trials available so far. Two of them revealed that the use of HCQ could be efficient in reducing the symptoms presented by patients with COVID-19 and decrease viral detection in the PCR test. Overall, studies have not reported the occurrence of serious side effects during the treatment. In the treatment of lupus, hydroxychloroquine is considered to be a safe medication that has mild side effects. The occurrence of severe adverse effects is rare and is generally related to the cumulative result of the medication or overdose ${ }^{29}$. Although these trials were carried out with few patients, it must be taken into account that the performance of clinical studies during the pandemic is hampered by the challenges brought by a new disease, especially concerning its course of development and symptoms presented by the patients.

Genetically, mutations in viral RNA also pose difficulties in establishing therapeutic strategies, such as the development of vaccines. In Brazil, the SARS-Cov-2 genome was sequenced at the Adolfo Lutz Institute and the analyzes indicated that the genome of the first Brazilian patient differs by three mutations from the reference strain in Wuhan, in China. Two of these changes are close to the German strain obtained in Munich, Bavaria ${ }^{30}$. It is crutial that the genomic sequencing of the virus in different research centers continues to be performed. This information must be shared with the world scientific community to enhance the understanding of the virus propagation and to assist in the development of new therapies for the emerging strains.

Despite all the efforts that have been made in the search for an effective treatment, the most effective measures for containing the virus are the WHO recommendations, such as social isolation, broad testing and home quarantine ${ }^{28}$. In a recent editorial, the Lancet pointed out that countries with a lethargic adoption of these recommendations at the initial phase were more drastically affected by the number of patients and deaths, as is the case of the United Kingdom, the United States and Sweden ${ }^{31}$. Brazil is also cited in the editorial, highlighting the weak response of its current president facing the SARS-CoV-2 pandemic. The article emphasizes that countries with fragile health systems should be overburdened soon if the infection is not contained. Despite the existence of few published clinical trials included in our meta-analysis, we believe that the use of HCQ is of paramount importance to prevent patients harboring COVID-19 with moderate symptoms to progress to severe symptoms. Mitigating the intensity of the symptoms would benefit the health systems, reducing the need for intensive care and the use of ventilators. 
According to the WHO, there are more than 40 studies of candidate vaccines against COVID-19, all in the development stage and being performed by teams from all over the world. As long as an effective vaccine is not developed, using existing drugs seems very attractive, since the development of a new drug can take years. HCQ is among these drugs, however, more clinical trials are still needed to validate its effectiveness for COVID-19. Designs of available clinical trials that have been included in this metaanalysis have important weaknesses that need to be considered. The studies did not perform tests of excellence as a randomized, multicenter, double-blind clinical trial. In addition, they do not meet the quality standards, especially with regard to patient screening. These deficiencies prevent its results from providing substantial evidence about the efficacy of hydroxychloroquine in the treatment of COVID-19. In spite of the result of this meta-analysis has suggested benefits for the use of hydroxychloroquine, the literature does not have studies that really demonstrate the superiority of this drug in controlling the pandemic. There are ongoing clinical studies, involving a large number of patients, which will provide more consistent evidence about the best treatment to use, which will help to establish individual treatment plans, where side effects are considered and the clinical status of each patient.

\section{Conclusion}

Although this meta-analysis found favorable evidence on the efficacy of HCQ for the treatment of patients with COVID-19, the included clinical trials have serious deficiencies that prevent them from providing consistent evidence. We believe that clinical trials coordinated by standardized guidelines, with complete and quality information, should be carried out worldwide and are urgently needed.

\section{Declarations}

\section{DATA AVAILABILITY STATEMENT}

The datasets generated during and/or analyzed during the current study are available from the corresponding author on reasonable request.

\section{FUNDING}

Not applicable.

\section{COMPETING INTERESTS}

The authors declare no conflicts of interest.

\section{AUTHOR CONTRIBUTIONS}

NIV, RP, STR designed the study. NIV, RP, STR, GLG, TFG, VRG analyzed the data, compilation, analysis and wrote the manuscript. STR performed statistical analysis. STR, VS, MS, KRL revised the manuscript. All authors approved the final manuscript. 


\section{References}

1. Report, C. d. C.-S. World Health Organization, <https://who.int/> (

2. Coronavirus COVID-19 outbreak: Latest news, information and updates. (2020).

3. Wu, Z. \& McGoogan, J. M. Characteristics of and Important Lessons From the Coronavirus Disease 2019 (COVID-19) Outbreak in China: Summary of a Report of 72314 Cases From the Chinese Center for Disease Control and Prevention. JAMA, doi:10.1001/jama.2020.2648 (2020).

4. Zhou, et al. Clinical course and risk factors for mortality of adult inpatients with COVID-19 in Wuhan, China: a retrospective cohort study. Lancet 395, 1054-1062, doi:10.1016/S0140-6736(20)30566-3 (2020).

5. Wang, D. et al. Clinical Characteristics of 138 Hospitalized Patients With 2019 Novel CoronavirusInfected Pneumonia in Wuhan, JAMA, doi:10.1001/jama.2020.1585 (2020).

6. Chen, et al. Epidemiological and clinical characteristics of 99 cases of 2019 novel coronavirus pneumonia in Wuhan, China: a descriptive study. Lancet 395, 507-513, doi:10.1016/S01406736(20)30211-7 (2020).

7. Bellani, G. et al. Epidemiology, Patterns of Care, and Mortality for Patients With Acute Respiratory Distress Syndrome in Intensive Care Units in 50 JAMA 315, 788-800, doi:10.1001/jama.2016.0291 (2016).

8. Savarino, , Boelaert, J. R., Cassone, A., Majori, G. \& Cauda, R. Effects of chloroquine on viral infections: an old drug against today's diseases? Lancet Infect Dis 3, 722-727, doi:10.1016/s14733099(03)00806-5 (2003).

9. Colson, , Rolain, J. M. \& Raoult, D. Chloroquine for the 2019 novel coronavirus SARS-CoV-2. Int J Antimicrob Agents 55, 105923, doi:10.1016/j.ijantimicag.2020.105923 (2020).

10. Colson, P., Rolain, J. M., Lagier, J. C., Brouqui, P. \& Raoult, D. Chloroquine and hydroxychloroquine as available weapons to fight COVID-19. Int J Antimicrob Agents, 105932, doi:10.1016/j.jjantimicag.2020.105932 (2020).

11. Wang, et al. Remdesivir and chloroquine effectively inhibit the recently emerged novel coronavirus (2019-nCoV) in vitro. Cell Res 30, 269-271, doi:10.1038/s41422-020-0282-0 (2020).

12. Gao, J., Tian, Z. \& Yang, X. Breakthrough: Chloroquine phosphate has shown apparent efficacy in treatment of COVID-19 associated pneumonia in clinical Biosci Trends 14, 72-73, doi:10.5582/bst.2020.01047 (2020).

13. Registry, C. T. Randomized, multicenter, controlled and randomized clinical trial of chloroquine phosphate in the treatment of new coronavirus pneumonia (COVID-19).

<http://www.chictr.org.cn/searchproj.aspx?title=\%E6\%B0\%AF\%E5\%96\%B9\&officialname=\&s ubjectid=\&secondaryid=\&applier=\&studyleader $=$ \&ethicalcommitteesanction=\&sponsor=\&st $\underline{\text { udyailment }=\& \text { studyailmentcode }=\& \text { studytype }=0 \& \text { studystage }=0 \& \text { studydesign }=0 \& \text { minstudyexe }}$ cutetime $=\&$ maxstudyexecutetime $=\&$ recruitmentstatus $=0$ \&gender $=0$ \&agreetosign $=\&$ secspon $\underline{\text { sor }=\& \text { regno }=\& \text { regstatus }=0 \& \text { country }=\& \text { province }=\& \text { city }=\& \text { institution }=\& \text { institutionlevel }=\& \text { meas }}$ 


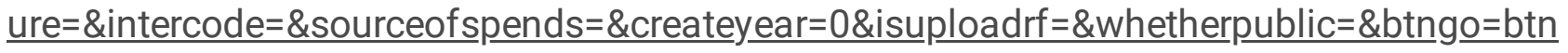

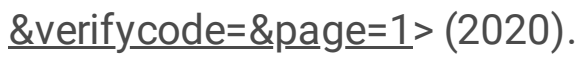

14. Marmor, M. F. et al. Recommendations on Screening for Chloroquine and Hydroxychloroquine Retinopathy (2016 Revision). Ophthalmology 123, 1386-1394, doi:10.1016/j.ophtha.2016.01.058 (2016).

15. Yao, X. et al. In Vitro Antiviral Activity and Projection of Optimized Dosing Design of Hydroxychloroquine for the Treatment of Severe Acute Respiratory Syndrome Coronavirus 2 (SARSCoV-2). Clin Infect Dis, doi:10.1093/cid/ciaa237 (2020).

16. Biot, et al. Design and synthesis of hydroxyferroquine derivatives with antimalarial and antiviral activities. J Med Chem 49, 2845-2849, doi:10.1021/jm0601856 (2006).

17. Jun, C. et (J Zhejiang Univ (Med Sci) 2020).

18. Gautret, et al. Hydroxychloroquine and azithromycin as a treatment of COVID-19: results of an openlabel non-randomized clinical trial. Int J Antimicrob Agents, 105949, doi:10.1016/j.ijantimicag.2020.105949 (2020).

19. Chen, Z. et (medRxiv 2020).

20. Zumla, \& Maeurer, M. Host-directed therapies for multidrug resistant tuberculosis. Int J Mycobacteriol 5 Suppl 1, S21-S22, doi:10.1016/j.ijmyco.2016.09.044 (2016).

21. Weniger, H. W. O. (Geneva : World health Organization, 1979).

22. Liu, J. et al. Hydroxychloroquine, a less toxic derivative of chloroquine, is effective in inhibiting SARSCoV-2 infection in Cell Discov 6, 16, doi:10.1038/s41421-020-0156-0 (2020).

23. McChesney, W. Animal toxicity and pharmacokinetics of hydroxychloroquine sulfate. Am J Med 75, 11-18, doi:10.1016/0002-9343(83)91265-2 (1983).

24. Organization, H. Coronavirus disease 2019 (COVID-19) Situation Report - 77, <https://www.who.int/docs/default-source/coronaviruse/situation-reports/20200406- sitrep-77covid-19.pdf?sfvrsn=21d1e632__2> (2020).

25. pneumonia, c. g. o. D. o. S. a. T. o. G. P. a. H. C. o. G. P. f. c. i. t. t. o. n. c. [Expert consensus on chloroquine phosphate for the treatment of novel coronavirus pneumonia]. Zhonghua Jie $\mathrm{He} \mathrm{He} \mathrm{Hu}$ Xi Za Zhi 43, 185-188, doi:10.3760/cma.j.issn.1001-0939.2020.03.009 (2020).

26. BRESCIA COVID RESPIRATORY SEVERITY SCALE (BCRSS); APPENDICE VADEMECUM DEL 13.03 SULLA GESTIONE DEL PAZIENTE AFFETTO DA COVID-19,<http://www.simit.org/medias/1581bcrssa1.pdf> (2020).

27. China issues guideline for regulating COVID-19 drug clinical trials, <http://www.xinhuanet.com/english/2020-02/28/c_138828090.htm> (2020).

28. Organization, W. H. A coordinated Global Research Roadmap, < $\underline{\text { https://www.who.int/blueprint/priority-diseases/key-action/Roadmap-version-FINAL-for- WEB.pdf? }}$ $\underline{\mathrm{ua}=1}>$ (2020). 
29. Ponticelli, \& Moroni, G. Hydroxychloroquine in systemic lupus erythematosus (SLE). Expert Opin Drug Saf 16, 411-419, doi:10.1080/14740338.2017.1269168 (2017).

30. @governosp. Governo de SP faz sequenciamento genético inédito de coronavírus na América Latina / Governo do Estado de São Paulo, <https://www.saopaulo.sp.gov.br/spnoticias/governo-de-sp-fazsequenciamento-genetico- inedito-de-coronavirus-na-america-latina/> (2020).

31. The COVID-19: learning from experience. Lancet 395, 1011, doi:10.1016/S0140-6736(20)30686-3 (2020).

\section{Tables}

Table 1 - Randomized clinical trials included in the meta-analysis

\begin{tabular}{|c|c|c|c|}
\hline Authors & Year & Study design & Evidence level \\
\hline Gautret, Philippe et al. & 2020 & Non-randomized clinical trial & 2b \\
\hline Chen, Zhaowei et al. & 2020 & Randomized clinical trial & $1 \mathrm{~b}$ \\
\hline Chen, Jun et al. & 2020 & Randomized clinical trial & $1 \mathrm{~b}$ \\
\hline
\end{tabular}

Table 2 - Clinical studies in progress. 


\begin{tabular}{|c|c|c|c|}
\hline $\begin{array}{l}\text { Registration } \\
\text { number }\end{array}$ & $\begin{array}{l}\text { Registration } \\
\text { date }\end{array}$ & Clinical Trials & $\begin{array}{l}\text { Country } \\
\text { registration }\end{array}$ \\
\hline ChiCTR2000029542 & 3-Feb-20 & $\begin{array}{l}\text { Study for the efficacy of chloroquine in patients with 2019-nCoV pneumonia (novel } \\
\text { coronavirus } \\
\text { pneumonia, NCP) }\end{array}$ & China \\
\hline ChiCTR2000029559 & 4-Feb-20 & $\begin{array}{l}\text { Therapeutic effect of hydroxychloroquine on } 2019-\mathrm{nCoV} \text { pneumonia (novel } \\
\qquad \text { coronavirus } \\
\text { pneumonia, NCP) }\end{array}$ & China \\
\hline ChiCTR2000029741 & 11-Feb-20 & $\begin{array}{l}\text { Efficacy of Chloroquine and Lopinavir/ Ritonavir in mild/general novel coronavirus } \\
\text { (CoVID-19) infections: a prospective, open- label, multicenter randomized controlled } \\
\text { clinical } \\
\text { study }\end{array}$ & China \\
\hline ChiCTR2000029760 & 12-Feb-20 & $\begin{array}{l}\text { A study for the efficacy of hydroxychloroquine } \\
\text { for mild and moderate COVID-19 infectious diseases }\end{array}$ & China \\
\hline ChiCTR2000029761 & $12-F e b-20$ & $\begin{array}{l}\text { Clinical study on the safety and effectiveness of Hydroxychloroquine Sulfate tablets in } \\
\text { the treatment of patients with novel coronavirus } \\
\text { pneumonia (COVID-19) }\end{array}$ & China \\
\hline ChiCTR2000029762 & $12-F e b-20$ & $\begin{array}{l}\text { Clinical study for the effect and safety of hydroxychloroquine sulfate tablets } \\
\text { in the treatment of patients with severe novel } \\
\text { coronavirus pneumonia (COVID-19) }\end{array}$ & China \\
\hline ChiCTR2000029803 & 14-Feb-20 & $\begin{array}{l}\text { A prospective, randomized, open-label, parallel controlled trial for the preventive effect } \\
\qquad \begin{array}{c}\text { of hydroxychloroquine on medical personnel after } \\
\text { exposure to COVID-19 }\end{array}\end{array}$ & China \\
\hline ChiCTR2000029868 & 15-Feb-20 & $\begin{array}{l}\text { Hydroxychloroquine treating novel coronavirus pneumonia (COVID-19): a multicenter, } \\
\text { randomized controlled trial }\end{array}$ & China \\
\hline ChiCTR2000029992 & 18-Feb-20 & $\begin{array}{l}\text { A prospective, randomized, open label, controlled trial for chloroquine and } \\
\qquad \begin{array}{c}\text { hydroxychloroquine in patients with severe } \\
\text { novel coronavirus pneumonia (COVID-19) }\end{array}\end{array}$ & China \\
\hline ChiCTR2000030054 & $22-F e b-20$ & $\begin{array}{l}\text { A prospective, open label, randomized, control trial for chloroquine or } \\
\qquad \text { hydroxychloroquine in } \\
\text { patients with mild and common novel }\end{array}$ & China \\
\hline
\end{tabular}




\begin{tabular}{|c|c|c|c|}
\hline & & coronavirus pulmonary (COVIP-19) & \\
\hline ChiCTR2000031174 & $\begin{array}{l}23- \\
\text { Mar- } \\
20\end{array}$ & $\begin{array}{l}\text { Effectiveness and safety of hydroxychloroquine sulfate in the preventive treatment of novel } \\
\text { coronavirus pneumonia (COVID-19) }\end{array}$ & China \\
\hline 2020-001010-38 & $\begin{array}{l}23- \\
\text { Mar- } \\
20\end{array}$ & $\begin{array}{l}\text { Norwegian coronavirus disease } 2019 \text { (no covid- } \\
\text { 19) study: an open labeled randomized controlled pragmatic trial to evaluate the } \\
\text { antiviral effect of chloroquine in adult patients } \\
\text { with sars-cov- } 2 \text { infection }\end{array}$ & Norway \\
\hline 2020-001281-11 & $\begin{array}{l}26- \\
\text { Mar- } \\
20\end{array}$ & $\begin{array}{l}\text { Evaluation of the concentration/viral effect } \\
\text { relationship of hydroxychloroquine in COVID- } 19 \text { patients in the intensive care unit. }\end{array}$ & France \\
\hline 2020-000890-25 & $\begin{array}{l}10- \\
\text { Mar- } \\
20\end{array}$ & $\begin{array}{l}\text { Treatment of Coronavirus SARS-Cov2 } \\
\text { Respiratory Infections with Hydroxychloroquine }\end{array}$ & France \\
\hline 2020-001224-33 & $\begin{array}{l}24- \\
\text { Mar- } \\
20\end{array}$ & $\begin{array}{l}\text { Randomized controlled trial of hydroxychloroquine versus placebo for the treatment of } \\
\qquad \begin{array}{c}\text { adult patients with acute } \\
\text { coronavirus disease } 2019 \text { - COVID-19 }\end{array}\end{array}$ & Germany \\
\hline \multirow[t]{2}{*}{$\begin{array}{l}30161220.0 .1001 .006 \\
0\end{array}$} & $\begin{array}{l}24- \\
\text { Mar- } \\
20\end{array}$ & $\begin{array}{l}\text { Estudo aberto, controlado, de uso de hidroxicloroquina e azitromicina para prevenção de } \\
\text { complicações em pacientes com infecção pelo novo coronavírus (COVID-19): Um estudo } \\
\text { randomizado e controlado }\end{array}$ & Brazil \\
\hline & $\begin{array}{l}25- \\
\text { Mar- } \\
20\end{array}$ & $\begin{array}{c}\text { Avaliação da segurança e eficácia clínica da Hidroxicloroquina associada à azitromicina em } \\
\text { pacientes com pneumonia causada por infecção pelo vírus SARS-Cov2 ALIANÇA COVID-19 } \\
\text { BRASIL II: PACIENTES GRAVES }\end{array}$ & Brazil \\
\hline NCT04329832 & $\begin{array}{l}1- \\
\text { Apr- } \\
20\end{array}$ & $\begin{array}{l}\text { Hydroxychloroquine vs. Azithromycin for Hospitalized Patients With Suspected or Confirmed } \\
\qquad \text { COVID-19 (HAHPS): A Prospective } \\
\text { Pragmatic Trial }\end{array}$ & USA \\
\hline NCT04329923 & $\begin{array}{l}1- \\
\text { Apr- } \\
20\end{array}$ & $\begin{array}{l}\text { The PATCH Trial (Prevention And Treatment } \\
\text { of COVID-19 With Hydroxychloroquine) }\end{array}$ & USA \\
\hline NCT04321993 & $\begin{array}{l}26- \\
\text { Mar- } \\
20\end{array}$ & $\begin{array}{l}\text { Treatment of Moderate to Severe Coronavirus } \\
\text { Disease (COVID-19) in Hospitalized Patients }\end{array}$ & Canada \\
\hline NCT04329611 & $\begin{array}{l}1- \\
\text { Apr- } \\
20\end{array}$ & $\begin{array}{l}\text { A Randomized, Double-blind, Placebo- controlled Trial to Assess the Efficacy and } \\
\text { Safety of Oral Hydroxychloroquine for the }\end{array}$ & Canada \\
\hline
\end{tabular}




\begin{tabular}{|c|c|c|c|}
\hline & & $\begin{array}{l}\text { Treatment of SARS-CoV-2 Positive Patients for } \\
\text { the Prevention of Severe COVID-19 Disease }\end{array}$ & \\
\hline NCT04333225 & $\begin{array}{l}\text { 3- } \\
\text { Apr- } \\
20\end{array}$ & $\begin{array}{l}\text { A Prospective Clinical Study of Hydroxychloroquine in the Prevention } \\
\text { of SARS- CoV-2 (COVID-19) Infection in } \\
\text { Healthcare Workers After High-risk Exposures }\end{array}$ & USA \\
\hline NCT04307693 & $\begin{array}{l}13- \\
\text { Mar- } \\
20\end{array}$ & $\begin{array}{l}\text { Randomized Controlled Clinical Trials of Lopinavir/Ritonavir or Hydroxychloroquine in Patients } \\
\qquad \text { With Mild Coronavirus Disease } \\
\text { (COVID-19) }\end{array}$ & $\begin{array}{l}\text { South } \\
\text { Korea }\end{array}$ \\
\hline NCT04323631 & $\begin{array}{l}26- \\
\text { Mar- } \\
20\end{array}$ & $\begin{array}{l}\text { Hydroxychloroquine for the Treatment of Patients With Mild to Moderate COVID-19 to Prevent } \\
\qquad \text { Progression to Severe Infection or } \\
\text { Death }\end{array}$ & Israel \\
\hline NCT04331834 & $\begin{array}{l}2- \\
\text { Apr- } \\
20\end{array}$ & $\begin{array}{c}\text { Pre-Exposure Prophylaxis With Hydroxychloroquine for High-Risk Healthcare Workers During the } \\
\text { COVID-19 Pandemic: A Unicentric, Double-Blinded Randomized } \\
\text { Controlled Trial }\end{array}$ & Spain \\
\hline NCT04329572 & $\begin{array}{l}1- \\
\text { Apr- } \\
20\end{array}$ & $\begin{array}{l}\text { Open, Multicentric, Non-Randomized, Exploratory Clinical Trial to Assess the Efficacy and Safety of } \\
\text { Hydroxychloroquine and Azithromycin for the Treatment of Acute Respiratory Syndrome (COVID- } \\
\text { 19) Caused } \\
\text { by SARS-CoV-2 Virus }\end{array}$ & Brazil \\
\hline NCT04315896 & $\begin{array}{l}20- \\
\text { Mar- } \\
20\end{array}$ & $\begin{array}{c}\text { Hydroxychloroquine Treatment for Severe COVID-19 Respiratory Disease: } \\
\text { Randomised Clinical Trial (HYDRA Trial) }\end{array}$ & Mexico \\
\hline NCT04330495 & $\begin{array}{l}1- \\
\text { Apr- } \\
20\end{array}$ & $\begin{array}{l}\text { Randomized, Controlled, Double-blind Clinical Trial Comparing the Efficacy and Safety of } \\
\text { Chemoprophylaxis With Hydroxychloroquine in Patients Under Biological Treatment and / } \\
\text { or JAKInhibitors in the Prevention of SARS-CoV- } \\
2 \text { Infection }\end{array}$ & Spain \\
\hline NCT04328493 & $\begin{array}{l}31- \\
\text { Mar- } \\
20\end{array}$ & $\begin{array}{c}\text { A Multi Center Randomized Open Label Trial on the Safety and Efficacy of Chloroquine for the } \\
\text { Treatment of Hospitalized Adults With Laboratory Confirmed SARS-CoV-2 Infection } \\
\text { in Vietnam }\end{array}$ & Vietnam \\
\hline NCT04333732 & $\begin{array}{c}\text { 3- } \\
\text { Apr- } \\
20\end{array}$ & A Phase 2, International Multi-site, Bayesian & USA \\
\hline
\end{tabular}




\begin{tabular}{|c|c|c|c|}
\hline & & $\begin{array}{l}\text { Adaptive, Randomised, Double-blinded, Placebo-controlled Trial Assessing the Effectiveness of } \\
\text { Varied Doses of Oral Chloroquine in Preventing or Reducing the Severity of COVID-19 Disease } \\
\qquad \begin{array}{c}\text { in Healthcare } \\
\text { Workers }\end{array}\end{array}$ & \\
\hline NCT04333654 & $\begin{array}{r}31- \\
\text { Mar- } \\
20\end{array}$ & $\begin{array}{l}\text { A Phase 1b, Randomized, Double-blinded, Placebo-controlled Study of Hydroxychloroquine } \\
\qquad \text { in Outpatient Adults } \\
\text { With COVID-19 }\end{array}$ & USA \\
\hline $\begin{array}{l}\text { IRCT2010022800344 } \\
9 \text { N27 }\end{array}$ & $\begin{array}{r}25- \\
\text { Mar- } \\
20\end{array}$ & $\begin{array}{l}\text { Evaluating efficacy and safety of interferone } \beta \text { - } \\
\text { 1b (IFN } \beta-1 b) \text { in the treatment of COVID-19 }\end{array}$ & Iran \\
\hline $\begin{array}{l}\text { IRCT2010022800344 } \\
9 N 28\end{array}$ & $\begin{array}{r}19- \\
\text { Mar- } \\
20\end{array}$ & $\begin{array}{l}\text { Evaluating efficacy and safety of interferone } \beta \text { - } \\
\text { 1a in the treatment COVID-19 infection }\end{array}$ & Iran \\
\hline $\begin{array}{l}\text { IRCT2010022800344 } \\
9 N 29\end{array}$ & $\begin{array}{r}19- \\
\text { Mar- } \\
20\end{array}$ & $\begin{array}{l}\text { Evaluating efficacy and safety of sofosbuvir/ } \\
\text { ledipasvir in treatment of COVID-19 }\end{array}$ & Iran \\
\hline jRCTs031190227 & $\begin{array}{r}27- \\
\text { Feb- } \\
20\end{array}$ & $\begin{array}{l}\text { A multicenter, open, prospective, single-arm study to assess the efficacy and safety of a } \\
\text { combination of lopinavir, ritonavir and hydroxychloroquine sulfate in a new } \\
\text { coronavirus infection }\end{array}$ & Japan \\
\hline NCT04303299 & $\begin{array}{r}24- \\
\text { Feb- } \\
20\end{array}$ & $\begin{array}{c}\text { A } 6 \text { Week Prospective, Open Label, Randomized, in Multicenter Study of, Oseltamivir Plus } \\
\text { Hydroxychloroquine Versus Lopipinavir/ Ritonavir Plus Oseltamivir Versus Darunavir/ } \\
\text { Ritonavir Plus Oseltamivir Plus Hydroxychloroquine in Mild COVID19 AND Lopipinavir/ } \\
\text { Ritonavir Plus Oseltamivir Versus Favipiravir Plus Lopipinavir / Ritonavir Versus Darunavir/ } \\
\text { Ritonavir Plus Oseltamivir Plus Hydroxychloroquine Versus Favipiravir Plus Darunavir and } \\
\text { Ritonavir Plus Hydroxychloroquine in Moderate to Critically } \\
\text { Ill COVID19 }\end{array}$ & Thailand \\
\hline ChiCTR2000029542 & $\begin{array}{r}2- \\
\text { Mar- } \\
20\end{array}$ & $\begin{array}{l}\text { Study for the efficacy of chloroquine in patients } \\
\text { with novel coronavirus pneumonia (COVID-19) }\end{array}$ & China \\
\hline NCT04261517 & $\begin{array}{r}6- \\
\text { Feb- } \\
20\end{array}$ & $\begin{array}{l}\text { Efficacy and Safety of Hydroxychloroquine for } \\
\text { Treatment of Pneumonia Caused by 2019-nCoV (HC-nCoV) }\end{array}$ & China \\
\hline ChiCTR2000029740 & $\begin{array}{r}11- \\
\text { Feb- } \\
20\end{array}$ & Efficacy of therapeutic effects of & China \\
\hline
\end{tabular}




\begin{tabular}{|c|c|c|c|}
\hline & & $\begin{array}{c}\text { hydroxycholoroquine in novel coronavirus pneumonia (COVID-19) patients } ₫ \text { randomized } \\
\text { open-label control clinical trial } \square\end{array}$ & \\
\hline ChiCTR2000029559 & $\begin{array}{r}2020- \\
\text { Feb- } \\
04\end{array}$ & $\begin{array}{l}\text { Therapeutic effect of hydroxychloroquine on } \\
\text { novel coronavirus pneumonia (COVID-19) }\end{array}$ & China \\
\hline NCT04316377 & $\begin{array}{r}20- \\
\text { Mar- } \\
20\end{array}$ & $\begin{array}{c}\text { Norwegian Coronavirus Disease } 2019 \text { Study: An Open Labeled Randomized Controlled Pragmatic } \\
\text { Trial to Evaluate the Antiviral Effect of Chloroquine in Adult Patients With SARS- } \\
\text { CoV-2 Infection }\end{array}$ & Norway \\
\hline
\end{tabular}

Table 3 - Frequency of symptoms at the beginning of treatment.

\begin{tabular}{|c|c|c|}
\hline \multirow{2}{*}{ Authors } & Group & Patients with symptoms at day 0 n (\%) \\
\hline \multirow{2}{*}{ Gautret, Philippe et al. } & HCQ & $18(90.0)$ \\
\hline \multirow{2}{*}{ Chen, Zhaowei et al. } & Control & $12(75.0)$ \\
\hline \multirow{2}{*}{ Chen, Jun et al. } & HCQ & $22(71.0)$ \\
\hline & Control & $17(54.8)$ \\
\hline & HCQ & $9(60.0)$ \\
\hline & Control & $13(86.7)$ \\
\hline
\end{tabular}

\section{Figures}


Databases searched

- PubMed;

- Google Scholar;

Key words used

Coronavirus;

COVID-19;

SARS-COV-2;

2019-Ncov;

Chloroquine;

Hydroxychloroquine.

Inclusion criteria were as follows

- Original studies;

- Researches on human;

- Full text can be found;

- Studies with a title or abstract including COVID-19 and

chloroquine or Hydroxychloroquine;

- Clinical trial studies.

Total articles found after removing duplicates: 214 .

Total articles included after selection criterion: 3 .

Excluded criteria were as follows

- Retrospective and in vitro studies, reviews, case reports, conference abstracts, proposals, and letters to editors;

- Duplicate publications and overlapping data from different databases;

- No sufficient data can be extracted for later evaluation.

Three reviewers evaluated the titles and assessed the full text of all articles independently to assess eligibility. Disagreement was resolved by consensus.

\section{Figure 1}

Flow diagram showing the selection process of clinical trials used in the meta-analysis. 


\section{Meta Analysis}

\begin{tabular}{|c|c|c|c|c|c|c|c|c|c|c|}
\hline \multirow[t]{2}{*}{ Study name } & \multicolumn{5}{|c|}{ Statistics for each study } & \multicolumn{4}{|c|}{ Odds ratio and $9596 \mathrm{CI}$} & \multirow[b]{2}{*}{$\begin{array}{l}\text { Relative } \\
\text { Weight }\end{array}$} \\
\hline & $\begin{array}{l}\text { Odds } \\
\text { ratio }\end{array}$ & $\begin{array}{l}\text { Lower } \\
\text { limit }\end{array}$ & $\begin{array}{l}\text { Upper } \\
\text { limit }\end{array}$ & Z-value & p-Value & & & & & \\
\hline Gautret, Fhilippe et a]. & 9.333 & 1.511 & 57.654 & 2.404 & 0.016 & & & & & 26.12 \\
\hline Chen, Zhaowes et al. & 8.233 & 2.482 & 27.317 & 3.445 & 0.001 & & & & & 60.21 \\
\hline \multirow[t]{4}{*}{ Chen, Jun et al. } & 2.154 & 0.174 & 26.672 & 0.598 & 0.550 & & & & & 13.68 \\
\hline & 7.082 & 2.793 & 17.960 & 4.123 & 0.000 & & & & T & \\
\hline & & & & & & 0.01 & 0.1 & 10 & 100 & \\
\hline & & & & & & & Control & $\mathrm{HCQ}$ & & \\
\hline
\end{tabular}

\section{Figure 2}

Forest plots showing the HCQ treatment in the patients with COVID-19. 